\title{
Escherichia coli Mutants Resistant to Uncouplers of Oxidative Phosphorylation
}

\author{
By MICHAEL R. JONES† AND R. BRIAN BEECHEY* \\ Department of Biochemistry and Agricultural Biochemistry, University College of Wales, \\ Aberystwyth, Dyfed SY23 3DD, UK
}

(Received 11 November 1986; revised 3 April 1987)

\begin{abstract}
Two mutant strains of Escherichia coli K12 Doc-S resistant to the uncoupling agents 4,5,6,7tetrachloro-2-trifluoromethyl benzimidazole and carbonyl cyanide $m$-chlorophenylhydrazone were isolated. These strains, designated TUV and CUV, were capable of $(a)$ growth, $(b)$ the transport of succinate and L-proline and $(c)$ electron-transport-linked oxidative synthesis of ATP in the presence of titres of uncoupler which inhibited these processes in strain Doc-S. The inhibition of transport of L-proline by a fixed titre of uncoupler was sharply $\mathrm{pH}$ dependent in strain Doc-S: uptake was unaffected at $\mathrm{pH} 7.6$ but completely inhibited at $\mathrm{pH} \mathrm{5.6}$. This $\mathrm{pH}$ dependence was not shown by the resistant strains. We believe that uncouplers were equally accessible to their site(s) of action in the energy-conserving membrane of the sensitive and resistant strains. We conclude that uncoupler resistance in these strains of $E$. coli has arisen as a consequence of mutations which directly affect a specific site of uncoupler action within the cytoplasmic membrane, rather than as a consequence of a decrease in the permeability of cells to uncoupler.
\end{abstract}

\section{INTRODUCTION}

Uncouplers such as the weak lipophilic acids 4,5,6,7-tetrachloro-2-trifluoromethyl benzimidazole (TTFB) (Beechey, 1966) and carbonyl cyanide $m$-chlorophenylhydrazone (CCCP) (Heytler, 1963) can act as protonophores, thereby dissipating the protonmotive force across energy-conserving membranes (Mitchell, 1961).

The existence of several uncoupler-resistant strains of Escherichia coli (Date et al., 1980: Ito \& Ohnishi, 1981; Ito et al., 1983; Sedgewick et al., 1984), Bacillus megaterium (Decker \& Lang, 1977, 1978; Guffanti et al., 1981) and a line of Chinese Hamster ovary cells (Freeman et al., 1983) has thrown doubt upon the competence of the protonophoric mechanism to fully account for the effects of uncoupling agents on energy-conserving membranes (Kell, 1982). This doubt is enhanced by data which show that uncouplers bind with high affinity to a small integral membrane protein from the energy-conserving membrane of prokaryote and eukaryote organisms (Katre \& Wilson, 1977, 1978, 1980; Partis et al., 1984). Resolution of the question as to whether uncouplers interact with proteins during the course of their action is important, since it bears upon the debate as to whether the proton movements responsible for coupling are 'delocalized' as is envisaged in the chemiosmotic hypothesis, or 'localized' as is envisaged in several alternative mechanisms devised to account for experimental observations incompatible with the chemiosmotic hypothesis (Ferguson, 1985).

In this paper we report the isolation and characterization of two distinct uncoupler-resistant strains of $E$. coli $\mathrm{K} 12$ Doc-S. The effects of uncouplers upon transport of L-proline by intact cells of the parent and resistant strains is further investigated.

$†$ Present address: Department of Biochemistry, University of Birmingham, PO Box 363, Birmingham B15 2TT, UK.

Abbreviations: TTFB, 4,5,6,7-tetrachloro-2-trifluoromethyl benzimidazole; CCCP, carbonyl cyanide $m$-chlorophenylhydrazone. 


\section{METHODS}

Materials. CCCP was purchased from Sigma. Fentrifanil [2'-chloro-2,4-dinitro-5',6-di(trifluoromethyl)diphenylamine] was a gift of Dr B. C. Baldwin (ICI Plant Protection Division, Jealott`s Hill Research Station, Bracknell, Berkshire, UK): SF6847 was a gift of Dr D. B. Kell (University College of Wales, Aberystwyth, Dyfed, UK). Cocktail T 'Scintran' scintillation fluid was purchased from BDH and L-[U- ${ }^{4}$ C $]$ proline from Amersham.

Organism and growth. E. coli K 12 Doc-S (laciz $y^{+} a^{+}$pro trp his met) was a gift of Dr I. R. Booth (University of Aberdeen, Aberdeen, UK). E. coli K 12 J. 53 (RP4) ( pro met $\mathrm{Str}^{\mathrm{s}} \mathrm{Tet}^{r} \mathrm{Carb}^{\mathrm{r}}$ ) was also used. LB medium contained $\left(I^{-1}\right) \mathrm{NaCl}(10 \mathrm{~g})$, tryptone $(10 \mathrm{~g})$ and yeast extract $(5 \mathrm{~g})(\mathrm{pH} 7.0)$. Three types of minimal medium were used, varying only in the nature of the primary carbon and energy source. All minimal media contained $\left(1^{-1}\right) 40 \cdot 2 \mathrm{~mm}-$ $\mathrm{K}_{2} \mathrm{HPO}_{4}, 22.0 \mathrm{~mm}-\mathrm{KH}_{2} \mathrm{PO}_{4}, 0.4 \mathrm{~mm}-\mathrm{MgSO}_{4}, 30.3 \mathrm{~mm}-\left(\mathrm{NH}_{4}\right)_{2} \mathrm{SO}_{4}, 1.7 \mathrm{~mm}-\mathrm{L}$-proline, $1.3 \mathrm{~mm}-\mathrm{L}-\mathrm{methionine}$ $1.3 \mathrm{~mm}-\mathrm{L}-$ histidine and $1.0 \mathrm{mM}-\mathrm{L}-\operatorname{tryptophan}(\mathrm{pH} \mathrm{7.0)}$. Disodium succinate, sodium acetate or D-glucose (44 mM) were added as required. All solid media contained $1.5 \%(w / v)$ agar (Lab $M$ ).

E. coli $\mathrm{K} 12$ Doc-S, E. coli K $12 \mathrm{~J} .53$ (RP4) and all uncoupler-resistant strains were maintained at $4{ }^{\circ} \mathrm{C}$ on slopes of LB medium. All growth in liquid culture was at $\mathrm{pH} 7.0$ and $30^{\circ} \mathrm{C}$ unless stated otherwise. Cultures were shaken on an orbital shaker at 160 r.p.m. in $100 \mathrm{ml}$ of liquid medium in $250 \mathrm{ml}$ Monod flasks. Growth was monitored using a Klett-Summerson colorimeter (no. 54 green filter) and expressed in Klett units. For experimental purposes all strains were grown from a standard inoculum $(0.1 \mathrm{ml}$ of an overnight culture in LB medium diluted to $130 \mathrm{Klett}$ units) in minimal medium containing either succinate or acetate or D-glucose as the primary carbon and energy source. Where appropriate cultures were supplemented aseptically with uncoupler after sterilization.

Isolation of the uncoupler-resistant strains. E. coli K 12 TUV was isolated by streaking E. coli K 12 Doc-S on to plates of succinate-minimal medium containing $100 \mu \mathrm{M}$-TTFB. Plates were exposed to $\mathrm{UV}$ light for $3 \mathrm{~h}$ following inoculation and were incubated at $30^{\circ} \mathrm{C}$ for $72 \mathrm{~h}$. E. coli $\mathrm{K} 12$ TUV was subcultured twice in succession from single colonies before preparation of stock slopes. E. coli K 12 CUV was isolated as above by streaking $E$. coli K 12 TUV on to plates of succinate-minimal medium containing $50 \mu \mathrm{M}$-CCCP.

Analysis of phenotype. Sensitivity to deoxycholate was assayed as described by Ahmed \& Booth (1983). $\beta$-Galactosidase activity in cells grown on succinate-minimal medium in the absence of uncoupler was assayed by the method of Miller (1972). The amino acid requirements of resistant and sensitive strains were tested by growing cells on amino-acid-deficient plates of succinate-minimal medium.

Cell harcesting. When the optical density of the growing culture had reached approximately 150 Klett units (late exponential phase), cells were harvested by centrifugation at $10000 \mathrm{~g}$ for $5 \mathrm{~min}$ at $4{ }^{\circ} \mathrm{C}$. The cells were washed twice by resuspension in the appropriate phosphate buffer (see below) followed by centrifugation at $10000 \mathrm{~g}$ for $5 \mathrm{~min}$ at 4 " $\mathrm{C}$, and were finally resuspended to $700-800 \mathrm{~K}$ lett units in the appropriate phosphate buffer. This gave stock cell suspensions containing 4-5 $\mathrm{mg}$ total cell protein $\mathrm{ml}^{-1}$.

Transport of L-proline. Assays of uptake of L-proline by stirred suspensions of whole cells were done in glass vessels at $37{ }^{\circ} \mathrm{C}$. Buffers were prepared by titrating $50 \mathrm{~mm}-\mathrm{KH}_{2} \mathrm{PO}_{4}$ with $50 \mathrm{~mm}-\mathrm{K}_{2} \mathrm{HPO}_{4}$ to give six different $50 \mathrm{~mm}$-phosphate buffers at $0.5 \mathrm{pH}$ unit intervals between $\mathrm{pH} 5.6$ and $\mathrm{pH} 8 \cdot 1$. Each assay system contained $0.2 \mathrm{ml}$

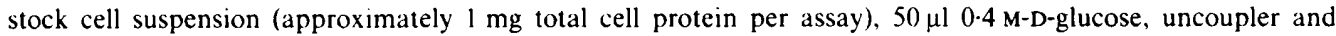
$1.75 \mathrm{ml}$ of the appropriate phosphate buffer. Cells were preincubated for $5 \mathrm{~min}$ before addition of $\mathrm{L}-[\mathrm{U}$ ${ }^{14} \mathrm{C}$ ]proline $\left[45 \mu \mathrm{M}, 27.7 \mathrm{Ci} \mathrm{mol}^{-1}\left(1.025 \mathrm{TBq} \mathrm{mol}^{-}\right)\right]$to give a final assay volume of $2 \mathrm{ml}$. At 45 and $90 \mathrm{~s}, 0.2 \mathrm{ml}$ samples were withdrawn and filtered through Millipore filters (type HA). Filters were washed with $5 \mathrm{ml}$ of the appropriate phosphate buffer, dried overnight at room temperature, dissolved in Cocktail $T$ 'Scintran' scintillation fluid and counted for radioactivity in an Intertechnique SL30 liquid scintillation counter.

\section{RESULTS}

\section{Phenotypic characteristics of the uncoupler-resistant strains}

E. coli Doc-S expresses the structural genes of the lac operon constitutively when grown on succinate-minimal medium. $\beta$-Galactosidase activity was detected in whole cells of strains DocS, TUV and CUV grown on succinate-minimal medium in the absence of uncoupler (data not shown) and all three strains had an absolute requirement for L-proline, L-tryptophan, L-histidine and L-methionine. E. coli Doc-S is unusually sensitive to the bile salt sodium deoxycholate (Ahmed \& Booth, 1983) and strains TUV and CUV showed the same sensitivity to deoxycholate over the range tested (2-7 mg per disc). A control strain, E. coli K $12 \mathrm{~J}$. 53 (RP4), was completely insensitive to deoxycholate over this range. Hence strains TUV and CUV retain the constitutive lac operon, amino acid requirements and deoxycholate-sensitivity that are characteristic of strain Doc-S. 


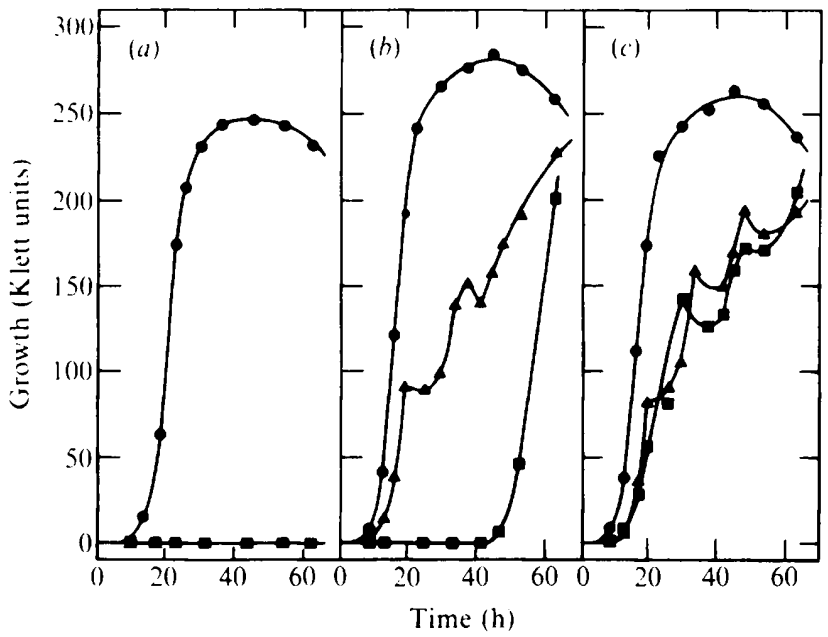

Fig. 1. Aerobic growth of $E$. coli Doc-S $(a)$, TUV $(b)$ and CUV $(c)$ at $30^{\circ} \mathrm{C}$ on succinate-minimal medium $(\mathrm{pH} \mathrm{7.())} \mathrm{in} \mathrm{the} \mathrm{absence} \mathrm{and} \mathrm{presence} \mathrm{of} \mathrm{TTFB} \mathrm{and} \mathrm{CCCP.} \mathrm{Growth} \mathrm{was} \mathrm{monitored} \mathrm{by}$ measuring optical density as described in Methods. Uncoupler was added to flasks aseptically after autoclaving.

No uncoupler:

A. $100 \mu \mathrm{M}-\mathrm{TTFB}: \square, 50 \mu \mathrm{M}-\mathrm{CCCP}$.

Table 1. Mean generation times of E. coli Doc-S, TUV and CUV grown on glucose-, succinateand acetate-minimal media in the absence of uncoupler

Cell growth was monitored by measuring the optical density as described in Methods. Cells were grown under aerobic conditions at $30^{\circ} \mathrm{C}$ and $\mathrm{pH} 7.0$ in minimal media containing $40 \mathrm{~mm}$ carbon source. Each value is presented as the mean $\pm \mathrm{SD}$ (no. of replicate determinations).

\begin{tabular}{lccc} 
Carbon & \multicolumn{3}{c}{ Mean generation time (min) } \\
source & Strain $\ldots$ & TUV & CUV \\
Glucose & $85 \pm 4(5)$ & $90 \pm 0(2)$ & $85 \pm 1(2)$ \\
Succinate & $184 \pm 15(2)$ & $124 \pm 9(2)$ & $132 \pm 13(2)$ \\
Acetate & $401 \pm 30(2)$ & $367 \pm 28(2)$ & $358 \pm 24(2)$
\end{tabular}

\section{Uncoupler-resistant growth on succinate}

In the absence of uncoupler, strain Doc-S grew more slowly on succinate-minimal medium than either strain TUV or CUV (Table 1) whereas no significant variation in the mean generation times was observed on acetate- or glucose-minimal media. In the absence of uncoupler the enhanced final optical density (Fig. 1) shown most markedly by strain TUV (and to a lesser extent by strain (UV) when compared with that of strain Doc-S was quite reproducible. It was reflected in the growth yields of the strains and was not due to an optical effect caused by swelling or shrinking of cells of a particular strain. Growth yields (calculated as $\mathrm{mg}$ total cell protein per flask) were $60.8 \mathrm{mg}$ for strain TUV, $50.4 \mathrm{mg}$ for strain CUV and $45.2 \mathrm{mg}$ for strain Doc-S. Growth of strain Doc-S on succinate-minimal medium was completely inhibited in the presence of $100 \mu \mathrm{M}$-TTFB or $50 \mu \mathrm{M}$-CCCP (Fig. $1 a$ ).

The growth of strain TUV was characterized by steps (Fig. lb). The position of these steps was irregular, occuring neither at a particular optical density nor time after inoculation, but they were always present. They were not caused by a change in the limiting nutrients for growth and were also present in growth curves based upon estimates of $\mathrm{mg}$ total cell protein per flask (data not shown). If succinate was omitted from the medium such that the amino acid supplement constituted the sole source of carbon, growth occurred with the same pattern of resistance as seen in the presence of succinate, but growth rates and yields were extremely poor. Strain TUV grew in the presence of $50 \mu \mathrm{M}-\mathrm{CCCP}$ (Fig. $1 \mathrm{~b}$ ) after a lag of $40-80 \mathrm{~h}$; this growth resulted from 


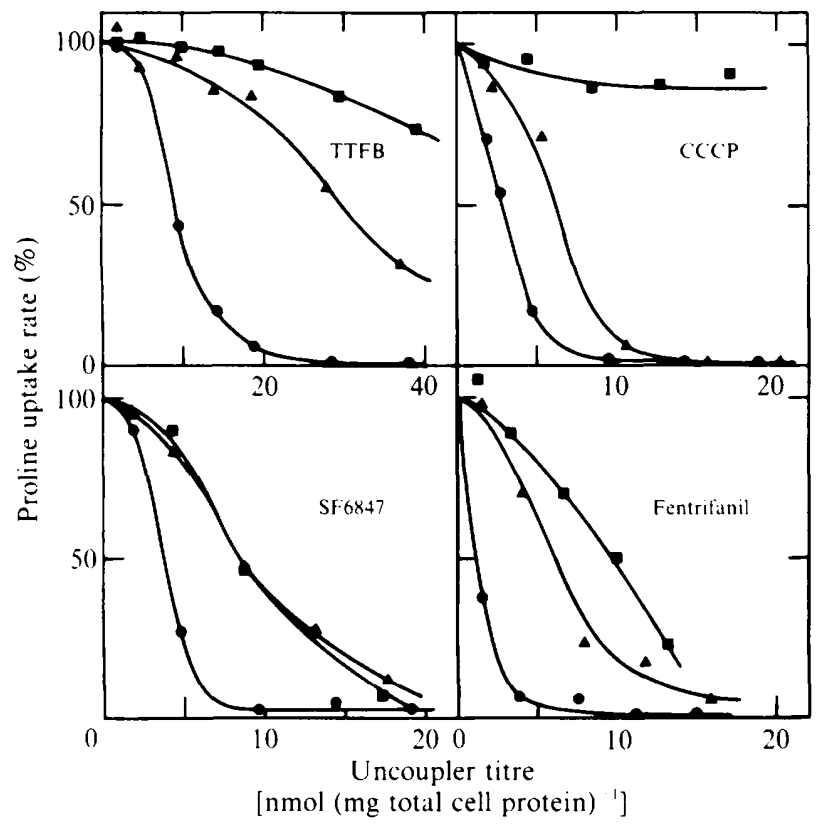

Fig. 2. Effect of TTFB, CCCP, SF6847 and Fentrifanil on rates of uptake of L-proline at pH 6.6 by whole cells of $E$. coli Doc-S, TUV and CUV. Cells were grown in succinate-minimal medium in the absence of uncoupler and harvested, prepared and assayed for L-proline transport as described in Methods. Cells were preincubated with uncoupler for $5 \mathrm{~min}$ before addition of $\mathrm{L}-\left[\mathrm{U}-{ }^{1+} \mathrm{C}\right]$ proline. Rates of uptake are expressed as percentages of the rate in an uninhibited incubation at pH 6.6 . Rates in the uninhibited incubations [expressed in units of $\mathrm{nmol} \mathrm{L}$-proline $\mathrm{min}^{-1}$ ( $\mathrm{mg}$ total cell protein $)^{-1}$ ] varied between 6.7 and 8.6 for strain Doc-S, 6.8 and 11.5 for strain TUV and 6.7 and 9.7 for strain CUV. E. coli Doc-S: $\boldsymbol{\Lambda}$, E. coli TUV: $\mathbf{\square}$, E. coli CUV.

Table 2. Accumulation of L-proline by intact cells of E. coli Doc-S, TUV and CUV at pH 6.6

Cells were grown on succinate-minimal medium, harvested, prepared and assayed for transport at pH 6.6 as described in Methods. Uptake was linear for at least the first $90 \mathrm{~s}$ in this experiment. The value of Ahmed \& Booth (1983) for the cytoplasmic volume of Doc-S [I.7 $\left.\mu \mathrm{l}(\mathrm{mg} \text { dry wt })^{-1}\right]$ was assumed in calculations of [proline $]_{\text {in }}$ for all three strains.

\begin{tabular}{|c|c|c|c|}
\hline Strain & $\begin{array}{l}{[\text { Proline }]_{\text {in }}{ }^{*}} \\
(\mathrm{mM})\end{array}$ & $\begin{array}{l}\text { Proline }]_{\text {out }}{ }^{*} \\
(\mathrm{mM})\end{array}$ & $\begin{array}{c}\text { Accumulation ratio } \dagger \\
\left.\text { ([Proline }]_{\text {in }} /[\text { Proline }]_{\text {out }}\right)\end{array}$ \\
\hline Doc-S & 3.63 & 0.039 & $92 \cdot 3 \pm 3 \cdot 1(2)$ \\
\hline TUV & $4 \cdot 40$ & 0.039 & $112.4 \pm 0.2(2)$ \\
\hline CUV & 3.63 & $0 \cdot 040$ & $91.8 \pm 1.8(2)$ \\
\hline
\end{tabular}

the appearance of double mutants resistant to both uncouplers. Strain CUV grew in the presence of $100 \mu \mathrm{M}$-TTFB and $50 \mu \mathrm{M}$-CCCP (Fig. 1c). In both cases growth was characterized by a stepped growth curve and a lag phase of less than $10 \mathrm{~h}$. We conclude that $E$. coli TUV and $E$. coli CUV are distinct uncoupler-resistant strains.

Growth was also studied on succinate-minimal medium at pH 6.1 (data not shown). Although all three strains grew in the absence of uncoupler at this $\mathrm{pH}$, they failed to grow in the presence of uncoupler over the time-scale of the experiment $(60 \mathrm{~h})$.

\section{Uncoupler-resistant growth on acetate}

Net synthesis of ATP by cells of $E$. coli growing on acetate as sole carbon and energy source can only occur via electron-transport-linked phosphorylation. In the presence of acetate strains 


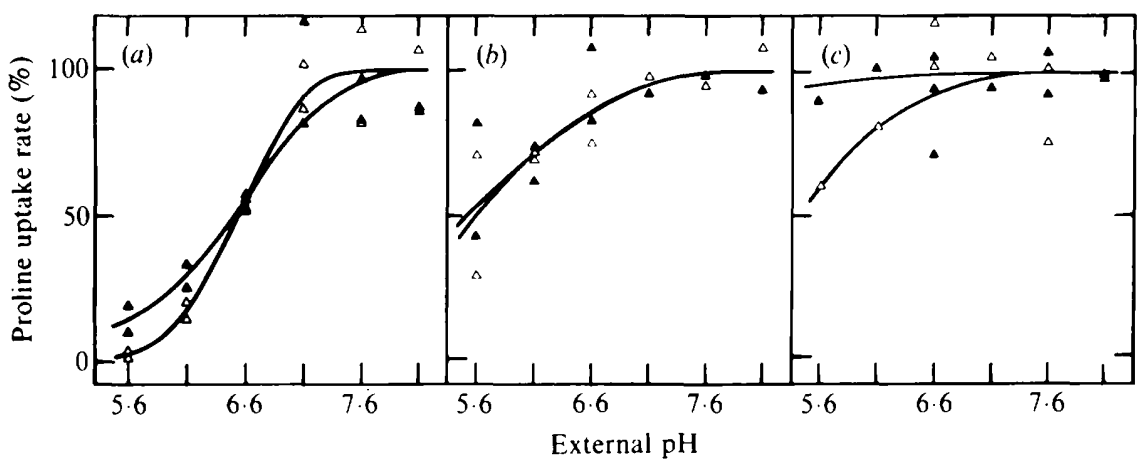

Fig. 3. pH dependence of the effect of uncouplers on the rate of uptake of L-proline by whole cells of $E$. coli Doc-S $(a)$, TUV $(b)$ and CUV $(c)$. Cells were grown on succinate -minimal medium in the absence of uncoupler and harvested, prepared and assayed for L-proline transport as described in Methods. Cells were preincubated with uncoupler for $5 \mathrm{~min}$ before addition of $\mathrm{L}-\left[\mathrm{U}-{ }^{1+4} \mathrm{C}\right]$ proline. Rates of uptake are expressed as a percentage of the rate in an uninhibited incubation at the appropriate pH. Rates of uptake in the uninhibited incubations varied between 4.5 and $9.3 \mathrm{nmol} \mathrm{L}$-proline $\mathrm{min}^{-1}\left(\mathrm{mg}^{2}\right.$ total cell protein $)^{-1} . \triangle, 9 \mathrm{nmol}$ TTFB $(\mathrm{mg} \text { total cell protein })^{-1} ; \Delta, 3 \mathrm{nmol}$ CCCP $(\mathrm{mg} \text { total cell protein })^{-1}$.

TUV and CUV showed the same resistance to $100 \mu \mathrm{M}$-TTFB and $50 \mu \mathrm{M}-\mathrm{CCCP}$ as seen for growth on succinate at $\mathrm{pH} 7.0$ (data not shown). Strain TUV did not grow in the presence of $50 \mu \mathrm{M}-\mathrm{CCCP}$ over the time-scale of the experiment $(80 \mathrm{~h})$. This uncoupler-resistant growth on acetate indicates that electron-transport-linked ATP synthesis can proceed in strains TUV and CUV in the presence of titres of uncoupler which inhibit growth of strain Doc-S on acetate.

\section{Effects of uncouplers on transport of L-proline}

Transport of L-proline in $E$. coli is energized by a protonmotive force and is normally uncoupler-sensitive (Kayama \& Kawasaki, 1976; Sabelnikov \& Domaradsky, 1981). Table 2 shows the accumulation of L-proline (as a ratio of the intra- and extracellular concentrations of $\mathrm{L}$ proline) after uptake had been allowed to proceed for $90 \mathrm{~s}$. During this period the uptake was linear. It was assumed that there was insignificant assimilation or oxidation of the accumulated L-proline. All three strains were capable of a 90- to 110 -fold accumulation of L-proline. The effect of uncouplers on the rate of uptake of $\mathrm{L}$-proline at $\mathrm{pH} 6.6$ by whole cells of strains Doc-S, TUV and CUV is shown in Fig. 2. In this experiment uncoupler was added to cells 5 min before the addition of $\mathrm{L}-\left[\mathrm{U}-{ }^{1+} \mathrm{C}\right]$ proline. Strain TUV showed a degree of resistance to all four uncouplers studied. Strain CUV showed the same level of resistance to SF6847 (Terada, 1975) as strain TUV (Fig. 2c) and showed some further increase in resistance to TTFB (Fig. 2a) and Fentrifanil (Nizamani \& Hollingworth, 1980) (Fig. 2d). Strain CUV was markedly more resistant to CCCP than strain TUV (Fig. 2h).

\section{$\mathrm{pH}$ dependence of inhibition of transport of L-proline}

The ability of a fixed titre of uncoupler to affect the rate of uptake of L-proline by whole cells was determined at an external $\mathrm{pH}$ ranging from 5.6 to 8.1 . The titres used were $3 \mathrm{nmol}$ CCCP and $9 \mathrm{nmol}$ TTFB (mg total cell protein) $)^{-1}$. These titres gave a $50 \%$ decrease in the rate of uptake by whole cells of strain Doc-S at pH 6.6.

In the absence of uncoupler the rate of uptake of L-proline by strain Doc-S showed no dependence on the external $\mathrm{pH}$ over the range 5.6 to 7.6 . Uptake was linear over at least the first $45 \mathrm{~s}$ under these conditions. The rate of uptake at $\mathrm{pH} 8 \cdot 1$ was half that seen at $\mathrm{pH} 5 \cdot 6$ to $7 \cdot 6$. Rates of uptake of L-proline by strains TUV and CUV in the absence of uncoupler were unaffected by variations in external $\mathrm{pH}$ over the range $5 \cdot 6$ to $8 \cdot 1$.

The effects of TTFB and CCCP on rates of uptake of L-proline by strain Doc-S showed a sharp dependence on external pH (Fig. $3 a$ ). The titres of uncoupler used effected almost total inhibition of uptake at $\mathrm{pH} 5.6$ but were completely ineffective at $\mathrm{pH} 7.6$. This dependence of uncoupler potency on external $\mathrm{pH}$ was not a reflection of changes in the $\mathrm{K}^{+}$concentration of the 
buffers used (from $52 \mathrm{~mm}$ at $\mathrm{pH} 5.6$ to $96 \mathrm{~mm}$ at $\mathrm{pH} 8.1$ ) nor was it dependent upon the time that cells were incubated with uncoupler before addition of $\mathrm{L}-\left[\mathrm{U}-{ }^{1+} \mathrm{C}\right]$ proline. The dependence on external $\mathrm{pH}$ was not evident to the same degree in cells of strains TUV or CUV. Both showed marked resistance to these titres of uncoupler over the range of external $\mathrm{pH}$ investigated (Fig. $3 b, c)$. Hence, in addition to showing resistance to the effect of a range of uncoupler titres at a fixed external $\mathrm{pH}$, strains TUV and CUV showed resistance to the effect of a fixed titre of uncoupler over a range of external $\mathrm{pH}$.

\section{DISCUSSION}

There are significant advantages to the use of $E$. coli $\mathrm{K} 12$ Doc-S as the parent strain for the isolation of mutants that are resistant to uncoupling agents. It has a leaky outer membrane that permits access to the cytoplasmic membrane of bulky negatively charged lipophilic molecules such as deoxycholate (Ahmed \& Booth, 1983) and uncouplers. In addition, it has an absolute requirement for $\mathrm{L}$-proline. The transport of this amino acid through the cytoplasmic membrane of the cell is principally facilitated by the PP-I complex, a Na+ $/$ proline symporter (Cairney et al., 1985 ) of $M_{\mathrm{r}} 24000$ defined by the put $P$ gene (Wood, 1981). Transport in the absence of a large external $\mathrm{Na}^{+}$concentration is energized by a protonmotive force and is sensitive to uncouplers (Kayama \& Kawasaki, 1976). Further, it is known that transport of succinate by the dicarboxylate carrier in $E$. coli also requires a protonmotive force and is uncoupler-sensitive (Gutowski \& Rosenberg, 1975). Hence, if strain Doc-S is to grow on succinate it must be able to actively transport L-proline and succinate, and synthesize ATP via electron-transport-linked phosphorylation.

The results of the growth experiments on succinate- and acetate-minimal medium demonstrate that strains TUV and CUV are able to carry out the active transport of L-proline and succinate, and electron-transport-linked ATP synthesis, in the presence of very high titres of uncoupler [55500 nmol TTFB ( $\mathrm{mg}$ total cell protein) ${ }^{-1}$ at the point of inoculation].

The possibility that the resistance to uncouplers is due to some modification of the permeability of the outer cell wall or outer membrane is highly unlikely. Strains TUV and CUV show the same sensitivity to deoxycholate as strain Doc-S. and hence have retained the leaky outer membrane of the parent strain. Strains TUV and CUV failed to grow on succinateminimal medium at $\mathrm{pH} 6.1$. We believe this was due to the deleterious acidification of the cytoplasm through the protonophoric activity of the uncouplers, and take this as demonstrating that cells of strains TUV and CUV were permeable to uncouplers under these conditions. Also, using the non-invasive technique of ${ }^{31} \mathrm{P}$ NMR, we have reported that TTFB will equilibrate the intra- and extracellular $\mathrm{pH}$ across the cytoplasmic membrane in whole cells of strains Doc-S and TUV (Jones et al., 1986). This demonstrates clearly that the uncoupling agents reach, and have comparable effects upon, the energy conserving membrane in these strains. We also infer from these data that, in the presence of uncoupling agents, the inner membrane of all three strains was freely permeable to protons under the growth conditions described here.

The pattern of uncoupler-resistance observed in the growth studies (with strain CUV being markedly more cross-resistant to CCCP than strain TUV) was also evident in their relative abilities to transport L-proline in the presence of these uncouplers. The $\mathrm{pH}$ dependence of uncoupler potency in strain Doc-S and the apparent lack of this dependence in strains TUV and CUV is interesting. A possible explanation for the sharp $\mathrm{pH}$ dependence of uncoupling in strain Doc-S is that at more acid $\mathrm{pH}$ values a greater percentage of the uncoupler is in the uncharged (protonated) form and hence more of the uncoupler can enter the lipid phase of the membrane. However, if this mechanism is valid it does not explain the lack of the sharp pH dependence in cells of strains TUV or CUV. Also, the influence of $\mathrm{pH}$ on the percentage of uncoupler in the uncharged form should be independent of the strain under study.

Previously, the only strain of $E$. coli in which uncoupler resistance had been clearly shown to be associated with a component of the cytoplasmic membrane was that described by Date $e t a l$. (1980). To our knowledge the nature of the mutation conferring uncoupler resistance on this strain has not been further investigated. Ito et al. (1983) claimed that their uncoupler-resistant 
strain of $E$. coli was associated with a mutation in the $\mathrm{H}^{+}$-translocating ATPase. This mutation prevented interactions between the $\mathrm{H}^{+}$-ATPase and inhibitors such as CCCP, pentachlorophenol, tributyltin and sodium azide. However, several of their observations indicated that CCCP could not longer act as a protonophore, which did not fit with this model for insensitivity to uncoupler. Sedgewick et al. (1984) recognized that the resistance to CCCP of $E$. coli UV6 could be caused by a decrease in the permeability of the outer membrane to uncoupler. However, they did not provide any firm evidence that the uncoupler resistance of the strain was not due to such a decrease in permeability. Nevertheless this remains the best characterized uncouplerresistant strain of $E$. coli.

The most extensively characterized uncoupler-resistant bacterium is the $B$. megaterium $\mathrm{C} 8$ strain of S. J. Decker and D. R. Lang. Studies on whole cells (Decker \& Lang, 1977, 1978; Guffanti et al.. 1981) and membrane vesicles (Guffanti et al., 1983) showed that malate-driven ATP synthesis at $\mathrm{pH} 7.4$ in this strain was CCCP-resistant. However malate-driven ATP synthesis at $\mathrm{pH} 5.5$ was uncoupler-sensitive in this strain and protonmotive-force-dependent transport of glycine and glutamine at $\mathrm{pH} 7.4$ was also uncoupler-sensitive. This contrasts with our observation that transport of L-proline is uncoupler-resistant in E. coli TUV and CUV, although it is interesting that as with malate-driven ATP synthesis in the C8 strain of $B$. megaterium, uncoupler-inhibition of transport of L-proline in $E$. coli Doc-S is $\mathrm{pH}$ dependent. The model devised for uncoupler resistance in $B$. megaterium was that strain C8 generated a larger membrane potential than the parent strain when the membrane was energized by malaterespiration. This enhanced potential was less vulnerable to dissipation by uncouplers, with the consequence that malate-respiration appeared to be more tightly coupled to ATP synthesis in the resistant strain. This tighter, 'localized' coupling was confined to the relation between respiration and $\mathrm{ATP}$ synthesis however, as respiration-driven amino acid transport remained uncoupler-sensitive.

The uncoupler-resistant strains described in this report are assumed to be capable of coupling both oxidative synthesis of ATP and active transport of L-proline and succinate to electron transport chain activity under conditions where the inner membrane is freely permeable to protons. The chemiosmotic hypothesis postulates that under such conditions a functional bulk phase protonmotive force cannot exist, unless proton translocation is unusually high. In the light of evidence that uncouplers can bind with high affinity to a small integral membrane protein from the energy-conserving membrane of prokaryotes and eukaryotes (Katre \& Wilson, 1977, 1978, 1980; Partis et al., 1984), we propose that in addition to their protonophoric activity, uncouplers such as TTFB and CCCP bind to a protein component of the bacterial inner membrane. The function of this protein is to facilitate the "localized" coupling of electron transport chain activity to oxidative ATP synthesis or active transport of L-proline and succinate. Uncoupling of this localized system is achieved by the steric hindrance of interactions between this protein and other protein complexes of the energy-conserving membrane brought about by the bound uncoupler. The mutations conferring uncoupler resistance modify the uncoupler binding site on this protein. The degree to which these modifications confer uncoupler resistance is dependent upon the structure and binding properties of individual uncouplers. If, as is feasible, the binding of uncouplers to this protein shows a dependence on $\mathrm{pH}$, then the $\mathrm{pH}$ dependence of uncoupling shown by strain Doc-S but not by strains TUV or CUV may merely reflect differences in the ability of uncouplers to bind to this protein in the parent and mutant strains.

This work was supported by the Science and Engineering Research Council, grant no. B/83/309573.

\section{REFERENCES}

Ahmed. S. \& Booth. I. R. (1983). The use of valinomycin, nigericin and trichlorocarbanilide in control of the protonmotive force in Escherichia coli cells. Biochemical Journal 212, 105112.

BEECHEY, R. B. (1966). The uncoupling of respiratorychain phosphorylation by 4.5.6.7-tetrachloro-2-tri- fluoromethyl benzimidazole. Biochenical Journal 98. 284-289.

Cairney, J., Higgins, C. F. \& Booth, I. R. (1985). Proline uptake through the major transport system of Salmonella typhimurium is coupled to sodium ions. Journal of Bacteriology 160, 22-27. 
DATE, T., ZWIZINSKI, C., LUDMERER, S. \& WiCKNER, W. (1980). Mechanisms of membrane assembly: effects of energy poisons on the conversion of soluble M13 coliphage procoat to membrane-bound coat protein. Proceedings of the National Academy of Sciences of the United States of America 77, 827-831.

DeCKer, S. J. \& LaNG, D. R. (1977). Mutants of Bacillus megaterium resistant to uncouplers of oxidative phosphorylation. Journal of Biological Chemistry 252, 5936-5938.

DeCKER, S. J. \& LANG, D. R. (1978). Membrane bioenergetic parameters in uncoupler-resistant mutants of Bacillus megaterium. Journal of Biological Chemistry 253, 6738-6743.

Ferguson, S. J. (1985). Fully delocalised chemiosmotic or localised proton flow pathways in energy coupling? A scrutiny of experimental evidence. Biochimica et biophysica acta 811, 47-95.

Freeman, K. B., Yatscoff, R. W., Mason, J. R., PATEL. H. V. \& BUCKLE, M. (1983). Characterisation of a Chinese Hamster Ovary cell line resistant to uncouplers. European Journal of Biochemistry 134, 215-222.

Guffanti, A. A., Blumenfeld, H. \& Krulwich, T. A. (1981). ATP synthesis by an uncouplerresistant mutant of Bacillus megaterium. Journal of Biological Chemistry 256, 8416-8421.

Guffanti, A. A., Fuchs, R. T. \& Krulwich, T. A. (1983). Oxidative phosphorylation by isolated membrane vesicles from Bacillus megaterium and its uncoupler-resistant mutant derivative. Journal of Biological Chemistry 258, 3537.

Gutowski, S. J. \& Rosenberg, H. (1975). Succinate uptake and related proton movements in Escherichia coli K12. Biochemical Journal 152, 647-654.

HEYTLER, P. G. (1963). Uncoupling of oxidative phosphorylation by carbonyl cyanide phenylhydrazones. I. Some characteristics of $m-\mathrm{Cl}-\mathrm{CCP}$ action on mitochondria and chloroplasts. Biochemistry 2, 357 361

ITo, M. \& OHNISHI, Y. (1981). Isolation of Escherichia coli mutants which are resistant to an inhibitor of $\mathrm{H}^{+}$-ATPase, tributyltin and also uncouplers of oxidative phosphorylation. FEBS Letters 136, 225230.

ITO, M.. OHNishi, Y., ITOH, S. \& NishimuRA, M. (1983). Carbonyl cyanide- $m$-chlorophenyl hydrazone-resistant Escherichia coli mutant that exhibits a temperature-sensitive unc phenotype. Journal of Bacteriology 153, 310-315.

Jones, M. R., Quirk, P. G., CaMPbell, I. D. \& BEECHEY, R. B. (1986). Uncoupler resistance in Escherichia coli: the effect of uncouplers on proline uptake, ATP levels and the transmembrane $\mathrm{pH}$ gradient. Biochemical Society Transactions 13, 888889.

KATRE, N. V. \& Wilson, D. F. (1977). Interaction of uncouplers with the mitochondrial membrane: a high-affinity binding site. Archives of Biochemistry and Biophysics 184, 578585.

KATRE, N. V. \& WILSON, D. F. (1978). Interaction of uncouplers with the mitochondrial membrane: identification of the high affinity binding site. Archives of Biochemistry and Biophysics 191, 647-656.

KatRe, N. V. \& Wilson, D. F. (1980). A specific uncoupler-binding protein in Tetrahy'mena pyriformis and Paracoccus denitrificans. Biochimica et biophysica acta 593, 224-229.

KaYAMa, Y. \& KaWASAKI, T. (1976). Stimulatory effect of lithium ion on proline transport by whole cells of Escherichia coli. Journal of Bacteriology 128, 157-164.

KELL, D. B. (1982). Bacteria that are resistant to uncouplers - what can they tell us? Trends in Biochemical Sciences 7, 1-2.

Miller, J. H. (1972). Experiments in Molecular Genetics, pp. 352-355. Cold Spring Harbor, New York: Cold Spring Harbor Laboratory.

Mitchell, P. (1961). Conduction of protons through the membranes of mitochondria and bacteria by uncouplers of oxidative phosphorylation. Biochemical Journal 81, 24P

Nizamani, S. M. \& Hollingworth, R. M. (1980). Fentrifanil: a diarylamine acaricide with potent mitochondrial uncoupling activity. Biochemical and Biophysical Research Communications 96, 704-710.

Partis, M. D., Griffiths, D. G. \& Beechey, R. B. (1984). Discrimination between the binding sites of modulators of the $\mathrm{H}^{+}$-translocating ATPase activity in rat liver mitochondrial membranes. Archives of Biochemistry and Biophysics 232, 610-615.

Sabelnikov, A. G. \& DomaradSky, I. V. (1981). Effect of metabolic inhibitors on entry of exogenous deoxyribonucleic acid into $\mathrm{Ca}^{+}$-treated Escherichia coli cells. Journal of Bacteriology 146, 435-443.

Sedgewick, E. G., Hou, C. \& BragG, P. D. (1984). Effect of uncouplers on the bioenergetic properties of a carbonyl cyanide $m$-chlorophenylhydrazoneresistant mutant Escherichia coli UV6. Biochimica et biophysica acta 767, 479-492.

Terada, H. (1975). Some biochemical and physicochemical properties of the potent uncoupler SF 6847 (3,5-di-tert-butyl-4-hydroxybenzylidene malononitrile). Biochimica et biophysica acta 387, 519-532.

Wood, J. M. (1981). Genetics of L-proline utilization in Escherichia coli. Journal of Bacteriology 146, 895-901. 